\title{
New and Traditional Multilateral Development Banks: Current and Potential Cooperation ${ }^{1}$
}

\section{A. Shelepov}

Andrey Shelepov - Researcher, Centre for International Institutions Research, Russian Presidential Academy of National Economy and Public Administration; 11 Prechistenskaya naberezhnaya, 119034 Moscow, Russian Federation; E-mail: shelepov-av@ranepa.ru

Most experts on multilateral development banks (MDBs) mention the possibility of large-scale co-financing in their forecasts concerning their future operations. However, interaction between MDBs and other actors, including co-financing, is rarely considered as a research problem for analytical and scientific papers. Yet this type of cooperation is one of the most important factors of effectiveness for the entire system of MDB financing. Thus, working in partnership with governmental institutions (development assistance agencies, export credit agencies, etc.), MDBs help attract additional financial resources and expertise in the countries where they are active. Working on state, regional and global levels, multilateral banks cooperate not only with governmental institutions, but also with private sector and civil society representatives. Such cooperation benefits both parties. In addition to mobilizing additional financial resources, it improves project preparation and implementation, taking into account national peculiarities, while partner institutions get a chance to use their experience and expertise. Given the recent establishment of the New Development Bank (NDB) and Asian Infrastructure Investment Bank $(A I I B)$, they are unlikely to achieve their main goal of narrowing the infrastructure financing deficit in developing countries without active cooperation with other institutions.

This article discusses the results and examines the prospects of the NDB and AIIB cooperating with traditional MDBs. It also focuses on the new banks' engagement with other financial institutions, including commercial banks and national development banks.

The author analyzes interbank memorandums and agreements as a formal basis for cooperation between various institutions, and examines in detail the examples of co-financing infrastructure projects by the new and traditional MDBs, as well as new multilateral cooperation mechanisms established by development banks.

The author concludes that the new banks' strategies differ from those of other institutions, and each has its own advantages. The AIIB seeks to establish cooperation primarily with large institutions to use their considerable experience and explore co-financing opportunities for large-scale projects. The NDB, with limited membership and geographical representation, focuses on, inter alia, cooperation with MDBs with a small number of participants, national development banks and commercial banks, which allows it to adopt the best international practices and gain experience in specific countries, receive consultative support for issuing bonds and improve financial management.

Key words: multilateral development banks (MDBs); New Development Bank (NDB); Asian Infrastructure Investment Bank (AIIB); co-financing; infrastructure

For citation: Shelepov A. (2017) New and Traditional Multilateral Development Banks: Current and Potential Cooperation. International Organisations Research Journal, vol. 12, no 1, pp. 127-147 (in Russian and English). DOI:10.17323/1996-7845-2017-01-127.

${ }^{1}$ The article is published within the framework of a research project "The prospects of the New Development Bank and Asian Infrastructure Investment Bank and their potential role in transforming the global financial architecture" (2016) of the Center for International Institutions Research (CIIR) of the Russian Presidential Academy of National Economy and Public Administration (RANEPA).

The editorial board received the article in November 2016. 


\section{Introduction}

Multilateral Development Banks (MDBs) make up the core of the system aimed at promoting global economic and social development. The persistent lack of investment in infrastructure, particularly in developing countries, and the aspiration of emerging economies for greater influence in global governance, in accordance with their positions in the world economy, have become key factors for the emergence of two new MDBs - the Asian Infrastructure Investment Bank (AIIB) and the New Development Bank (NDB). Accordingly, research interest has grown in studying various aspects of MDBs' work and analyzing key differences between the new and "traditional" development banks. A number of papers, including [Humphrey, 2015] and [GriffithJones, 2014] are devoted to examining the growth prospects of the NDB and AIIB loan portfolios, comparative scenarios of their development, and underlying factors. Other authors, including [Bhattacharya, Oppenheim, Stern, 2015] focus their research on insufficient investment in infrastructure, assessing relevant needs and potential MDB involvement in bridging the gap. The history of "traditional" MDBs, including the International Bank for Reconstruction and Development (IBRD) and leading regional banks, has been studied comprehensively. Finally, national development institutions, including development banks of developing countries, are subject to active studies [Barone, Spratt, 2015].

In their studies, most experts mention the possibility of large-scale co-financing in their forecasts for future operations of development institutions. However, interaction between MDBs and other actors, including in co-financing of projects, is barely considered as a separate research problem. Nevertheless, this type of cooperation is one of the most important factors in the effectiveness of the entire system of financing through MDBs. Working in partnership with governmental institutions (development assistance agencies, export credit agencies, etc.), MDBs contribute to attracting additional financial resources and expertise in countries where they are active. Working on the state, regional and global levels, multilateral banks cooperate not only with governmental institutions, but also with private sector and civil society representatives. Such cooperation is usually beneficial to both parties. In addition to mobilizing additional financial resources, it contributes to improving the preparation and implementation of projects, taking into account national circumstances, while MDBs' partner institutions get the chance to use their experience and expertise. ${ }^{2}$

In addition, interaction between MDBs remains an important aspect of cooperation. MDBs' joint activities also help to develop the general principles for effective

${ }^{2}$ Swiss State Secretariat for Economic Affairs. Co-financing of the multilateral development banks. Available at: http://www.seco-cooperation.admin.ch/themen/multilateral/00525/index. html?lang=en (accessed 08 December 2016). 
work, consolidate expertise, and significantly increase the volume of resources available for projects. ${ }^{3}$

Given that the NDB and AIIB have not remained outside the trend of increasing cooperation between MDBs, studying the prospects of their development and assessing the potential to fulfill their core mission - to narrow the global gap in infrastructure financing - is impossible without realizing the potential for strengthening cooperation within the existing MDB system, primarily between the newly created banks on the one hand and "traditional" ones on the other. In this regard, the article provides an analysis of the nature of documents (memoranda of cooperation, co-financing agreements, etc.), both signed and planned, between the NDB, AIIB and other financial institutions; affirmed and prospective volumes of co-financing in the framework of this cooperation; the scale and dynamics of non-financial engagement (e.g., exchange of experience and best practices); and joint participation of the new and "traditional" MDBs in various multilateral initiatives. Analysis of various aspects of interaction between the new and "traditional" MDBs, the and priorities of NDB and AIIB cooperation with other institutions, also allows us to draw conclusions as to which operational niches member countries want the new banks to occupy.

\section{Interbank memoranda and agreements as a formal basis for cooperation}

\section{Asian Infrastructure Investment Bank}

The new financial institutions are actively cooperating with both regional development banks and the World Bank Group (WBG) on the basis "institutional strengths and comparative advantages, and mutual benefit" [AIIB and ADB, 2016].

The first step in formalizing the AIIB's cooperation with other MDBs was the signing of a Co-Financing Framework Agreement with the World Bank. This agreement defined the main parameters for the co-financing of investment projects by the two institutions. It was stated that in 2016 the AIIB expected to approve about USD1.2 billion in financing, with World Bank joint projects anticipated to account for a sizable share. The importance of the proposed cooperation is highlighted by the largescale contributions of the WBG to addressing the global gap in infrastructure investment. During the fiscal year 2014-15, the WBG institutions invested USD18.8 billion in infrastructure projects. In the future, there are plans not only to increase this volume by expanding the portfolios of the International Finance Corporation and the Multilateral Investment Guarantee Agency, but also to actively raise funds and use the expe-

${ }^{3}$ Asian Development Bank. Cofinancing Partnerships. Available at: https://www.adb.org/ site/cofinancing/main (accessed 08 December 2016). 
rience of other banks and private investors, including in the framework of the Global Infrastructure Facility. ${ }^{4}$ This mechanism was established by the World Bank with G20 support as an important element complementing the G20's work on attracting private investment in infrastructure [Multilateral Development Banks, 2016].

As part of the agreement, the World Bank and AIIB launched discussions on about 10 joint projects in transport, water supply and the energy sectors in Central, South and East Asia. Importantly, this agreement provides not only for funding by the two institutions, but also for the implementation of preparatory and supervision functions by the World Bank in accordance with its policies and procedures, in such areas as procurement, environmental protection and social safeguards. ${ }^{5}$

On 2 May 2016, AIIB President Liqun Jin and ADB President Takehiko Nakao signed a memorandum of understanding on the sidelines of the ADB Board of Governors' $49^{\text {th }}$ annual meeting. According to the representatives of the banks, the signing of this agreement laid the foundation for project co-financing. It was noted that the AIIB and ADB were already discussing projects for co-financing in the road construction and water sectors. The first joint project was expected to be the construction of a 64-kilometer section of the M4 highway in Pakistan, connecting the cities of Shorkot and Khanewal in Punjab province. The signed document mentioned that the two institutions would "strengthen cooperation, including co-financing, at the strategic and technical levels on the basis of complementarity and value added" [AIIB and ADB, 2016]. The heads of the institutions noted that their cooperation began at the stage of the AIIB establishment process, and is aimed at addressing infrastructure financing needs in Asia, taking into account the objectives of promoting sustainable growth, reducing poverty, and fighting climate change in the region. The priority areas of cooperation include energy, transportation, telecommunications, agriculture and rural development, water resources, urban development, and environmental protection. The parties also agreed to hold regular high-level consultations between their representatives and undertake joint data collection in order to facilitate the agreement's implementation. ${ }^{6}$

On 11 May 2016 during the 25th annual meeting of the EBRD in London, AIIB President Jin Liqun and his EBRD counterpart Suma Chakrabarti signed a Memorandum of Understanding between the two institutions. Similarly to the ADB case, cooperation between the EBRD and AIIB began when the latter was established. It was noted

\footnotetext{
${ }^{4}$ Global Infrastructure Facility, World Bank Group, 2016. Available at: http://www.worldbank.org/en/programs/global-Infrastructure-facility (accessed 08 December 2016).

${ }^{5}$ AIIB and World Bank sign first Co-Financing Framework Agreement. Asian Infrastructure Investment Bank, 2016. Available at: https://www.aiib.org/en/news-events/news/ 2016/20160414 002.html (accessed 08 December 2016).

${ }^{6} \mathrm{AIIB}, \overline{\mathrm{ADB}}$ sign $\mathrm{MOU}$ to strengthen cooperation for sustainable growth. Asian Infrastructure Investment Bank, 2016. Available at: https://www.aiib.org/en/news-events/news/ 2016/20160502_001.html (accessed 08 December 2016).
} 
that even before the signing of the document, the EBRD shared with the new institution its experience in such areas as investment processes and the implementation of infrastructure and energy projects. However, the main focus of cooperation, given the AIIB's regional specifics, was infrastructure development in Asia. According to the heads of the two institutions, cooperation will take place in the form of regular dialogue at the senior management level, exchange of information on their policies and strategies, and activities in common areas where both banks invest in infrastructure projects. The banks announced specific cooperation projects. In particular, AIIB representatives were expected to consider possible financing for the construction of a road linking the Tajik capital, Dushanbe, with the Uzbek border, which will be part of the east-west transport corridor in Central Asia in the near future. ${ }^{7}$ The EBRD Board of Directors approved the first tranche of funding for this project totaling USD35 million in 2012, and on 4 May 2016 decided to allocate a second tranche of USD27.5 million [AIIB, 2016h]. Specific parameters of the project are analyzed further in this article. Currently, the two banks are considering other potential joint infrastructure projects in Central Asia. In addition, AIIB support for the EBRD's "services related to project environmental and social safeguards" of the co-financed projects, and "procurement and other matters," on a cost-sharing basis, has become an important element of the cooperation agreement between the two institutions [EBRD and AIIB, 2016]. Thus, the AIIB intends not only to use a synergistic effect for consolidating infrastructure funding, but also to improve its international image in response to widespread concerns about its compliance with best international standards related to the social and environmental policies of development banks.

On 30 May 2016, a Memorandum of Understanding between the AIIB and the European Investment Bank was signed. The two institutions agreed to broaden their cooperation to support investment in strategically important projects, co-finance projects, and expand cooperation in countries where both of them carry out operations. It is important to note that unlike the other AIIB partner institutions discussed above, the European Investment Bank does not consider projects in developing countries as the only priority, and is actively promoting, inter alia, infrastructure development in Europe. The main areas of cooperation defined in the Memorandum include ensuring sustainable transport development, providing access to clean water, and tackling climate change [AIIB and EIB, 2016]. As with the other institutions considered, cooperation between the AIIB and the European Investment Bank had started before the signing of the relevant document, especially in the form of exchange of technical and financial expertise. The joint document was characterized as a stimulus for augmenting this cooperation, including through streamlining the co-financing of projects and ensuring regular dialogue between the two institutions' staff. Given the AIIB's

${ }^{7}$ Asian Infrastructure Investment Bank to cooperate with European Bank for Reconstruction and Development. Asian Infrastructure Investment Bank, 2016. Available at: https://www.aiib.org/ en/news-events/news/2016/20160511_001.html (accessed 08 December 2016). 
commitment to providing "green" financing, it is important to note that the European Investment Bank is the largest lender for climate-related investment and the global leader in issuing green bonds. ${ }^{8}$

\section{New Development Bank}

Compared to the AIIB, the NDB was initially less active in developing cooperation with other MDBs. However, recent steps in this area highlight the bank's aspiration to establish cooperation with international institutions working in its priority countries and sectors.

On 4 July 2016, NDB President Kudnapur Kamath and ADB President Takehiko Nakao signed a Memorandum of Understanding between the two institutions. The main purpose of the memorandum was to facilitate and develop cooperation between the NDB and the ADB, in order to identify areas of strategic partnership and joint interests of the two institutions. As noted by T. Nakao, "This framework of collaboration is a significant milestone for ADB-NDB cooperation. As the region's development landscape is continuously evolving, we will strengthen our cooperation in achieving sustainable, balanced, and inclusive growth and poverty reduction in countries of common interest." In turn, K. Kamath said that the memorandum provides a framework for sharing knowledge, and an opportunity to discuss co-financing of projects. It was decided that the main areas of cooperation in the framework of the memorandum would include sustainable development projects in renewable energy, energy efficiency, clean transportation, water management and sewage treatment. ${ }^{9}$

Cooperation between the NDB and the World Bank was formalized on 9 September 2016. The two institutions signed a Memorandum of Understanding, providing for cooperation in implementing projects, especially in infrastructure, including in the field of energy and water supply. Potential areas of cooperation mentioned in the MoU include co-financing of projects, knowledge exchange regarding their operations, advisory services, and the development of mechanisms for staff exchanges. As NDB President K. Kamath noted, the bank "appreciates timely support offered by the World Bank Group throughout our establishment process, and looks forward to advancing and deepening cooperation... The NDB will listen, learn and collaborate to promote sustainable infrastructure development in... member countries." 10

\footnotetext{
${ }^{8}$ Asian Infrastructure Investment Bank and European Investment Bank agree to strengthen cooperation. Asian Infrastructure Investment Bank, 2016. Available at: https://www.aiib.org/en/ news-events/news/2016/20160530_001.html (accessed 08 December 2016).

${ }^{9} \mathrm{NDB}, \mathrm{ADB}$ sign MOU on cooperation for sustainable, inclusive growth. New Development Bank, 2016. Available at:http://www.ndb.int/ndb-adb-sign-mou-on-cooperation-for-sustainableiclusive-growth.php\#parentHorizontalTab2 (accessed 08 December 2016).

${ }^{10}$ World Bank Group, New Development Bank Lay Groundwork for Cooperation. World Bank Group, 2016. Available at: http://www.worldbank.org/en/news/press-release/2016/09/09/world-
} 
On the same day, a Memorandum of Understanding between the NDB and the Development Bank of Latin America (CAF) was signed. The main objective of the memorandum was to stimulate mutually beneficial activities of the two institutions in common areas, including sustainable infrastructure development, energy, water supply and environmental protection projects. The document also provides for the possibility of co-financing projects in the priority countries of both banks, and highlights the need to facilitate knowledge and expertise exchange through joint activities. A special emphasis is made on the complementary objectives of the two banks, given that the CAF is active in Latin American and Caribbean countries. ${ }^{11}$ In contrast to the documents between the NDB and other banks, this MoU highlights that cooperation will be bilateral and balanced, meaning that exchanges of experience and best practices will be carried out on a reciprocal basis. ${ }^{12}$

Unlike the AIIB, the NDB demonstrates examples of formalizing cooperation not only with MDBs, but also with commercial banks and national development banks of its member countries.

One of the largest private banks in India, ICICI (Industrial Credit and Investment Corporation of India), signed a memorandum of cooperation with the NDB on 5 May 2016. It should be noted that NDB President K. Kamath is a former head of ICICI. Under the memorandum the two institutions will view each other as "privileged partners." In addition to standard areas of cooperation such as exchanges of experience and best practices and co-financing of projects, the memorandum between the NDB and ICICI provides for cooperation in bond issuance, treasury management, and risk management. According to K. Kamath, the signing of the memorandum should help the NDB to better understand the peculiarities of the Indian financial market, facilitate access to this market, and in the long term, facilitate the issuance of rupee-denominated bonds on Indian and international markets. ${ }^{13}$ Following the recent successful RMBdenominated bond issuance, doing the same with rupee-denominated bonds is one of the Bank's priorities for 2017. ${ }^{14}$

bank-group-new-development-bank-lay-groundwork-for-cooperation (accessed 08 December 2016).

${ }^{11} \mathrm{CAF}$ and New Development Bank Sign Cooperation Agreement. Development Bank of Latin America, 2016. Available at: https://www.caf.com/en/currently/news/2016/09/caf-and-newdevelopment-bank-sign-cooperation-agreement/ (accessed 08 December 2016).

${ }_{12}$ Development Banks CAF and NDB Agree to co-operate more closely. New Development Bank, 2016.Available at: http://www.ndb.int/Development-banks-CAF-and-NDB-agree-to-cooperate-more-closely.php (accessed 08 December 2016).

${ }^{13}$ ICICI Bank signs MoU with BRICS Grouping-Promoted New Development Bank. New Development Bank, 2016. Available at: http://ndb.int/ICICI-Bank-signs-MoU-with-BRICSGrouping-promoted-New-Development-Bank.php (accessed 08 December 2016).

${ }^{14}$ New Development Bank Plans Rupee, Rouble Bonds. New Development Bank, 2016. Available at: http://ndb.int/New-Development-Bank-plans-rupee-rouble-bonds.php (accessed 08 December 2016). 
In July 2016, a Memorandum of Understanding on cooperation in the same areas (co-financing, assistance in bond issuance, etc.) was signed between the NDB and the China Construction Bank. Under this MoU, the China Construction Bank provided support to the NDB in issuing green bonds on the Chinese market. ${ }^{15}$

On 31 August 2016, the NDB signed another document of a similar nature with a commercial bank from one of the BRICS countries, namely with one of the largest banking institutions in emerging markets, Standard Bank of South Africa Limited (SBSA), which became its new strategic cooperation partner. ${ }^{16}$

As for cooperation with national development banks, the main result was a Memorandum of Intent on Cooperation between banks participating in the BRICS Interbank Cooperation Mechanism and the NDB at the Ufa summit in July 2015. The memorandum was signed by the State Corporation "Bank for Development and Foreign Economic Affairs (Vnesheconombank)" (Russia), the Development Bank of Brazil (Banco Nacional de Desenvolvimento Economico e Social (BNDES)), the China Development Bank (CDB), the Export-Import Bank of India (Eximbank) and the Development Bank of Southern Africa. The BRICS Interbank Cooperation Mechanism involving these institutions was established in accordance with a Memorandum on cooperation between the state financial institutions for development and export support of the BRICS nations in 2010. In 2011, following South Africa's accession to the BRICS, the Memorandum was signed by an authorized financial institution of this country - the Development Bank of South Africa. The document declared the following main objectives of the Mechanism: the development of a comprehensive longterm interbank cooperation between the partners aimed at strengthening economic and trade relations between BRICS member countries, and supporting the implementation of socially important and regional projects.

The Memorandum signed at the Ufa summit expressed declarative intentions of the BRICS countries' development banks to interact with the NDB in line with specific parameters and directions. In particular, the document provides for potential cooperation in infrastructure and sustainable development, which is fully consistent with the NDB mandate. As noted by Vnesheconombank Chairman Vladimir Dmitriev, "banks participating in the BRICS Interbank Cooperation Mechanism and the New Development Bank have similar objectives, and that is why our cooperation will have a positive influence on the development of the BRICS countries' economies."17

${ }^{15}$ New Development Bank Signs MoU With China Construction Bank. BRICS Information Sharing and Exchange Platform, 2016. Available at: http://www.brics-info.org/new-developmentbank-signs-mou-with-china-construction-bank/ (accessed 08 December 2016).

${ }^{16} \mathrm{NDB}$ and Standard Bank of South Africa signed Memorandum on strategic cooperation. New Development Bank, 2016. Available at: http://ndb.int/NDB-AND-STANDARD-BANKOF-SOUTH-AFRICA.php\#parentHorizontalTab2 (accessed 08 December 2016).

${ }^{17}$ Heads of Banks participating in the BRICS Cooperation Mechanism intend to cooperate with the New Development Bank. Vnesheconombank, 2015. Available at: http://www.veb.ru/en/ press/news/?id_19=100890 (accessed 08 December 2016). 
The agreement on concrete measures represented a further step in this area of cooperation. On 13 October 2016, the government of India approved the participation of "the Export-Import Bank in signing an agreement with the New Development Bank through the BRICS Interbank Cooperation Mechanism." The main purpose of this document was reported to be strengthening trade and economic relations between the BRICS countries, in particular, increasing mutual investments. Representatives of India noted that the document would be nonbinding in nature, and would represent a "cooperation framework in accordance with the national laws and regulations, besides skills transfer and knowledge sharing amongst the signatories," and that "There is no financial implication involved with signing of the MoU.” 18

On 16 October 2016, the NDB and members of the BRICS Interbank Cooperation Mechanism signed a Memorandum of Understanding on general cooperation. This was a logical development of a document on cooperation signed in 2015, and specified the following areas of cooperation:

Financing and co-financing of projects;

- lines of credit, including two-step and back-to-back loan facilities;

- currency swaps, interest rate swaps and other derivatives;

- issuance of bonds;

- joint programs for project finance;

- public-private partnerships at sovereign and sub-sovereign levels;

- guarantees and counter-guarantees to secure obligations;

- development of effective and sustainable financing solutions for projects of mutual interest;

- investment funds to finance projects in priority sectors;

- experience and knowledge-sharing in the area of technical assistance for the preparation and implementation of development projects;

- experience and knowledge-sharing in the development of policies and procedures relating to environmental and social standards, and procurement;

- exchanges of personnel and other forms of cooperation in human resource management;

- joint publications, organization of conferences, round tables and other events;

- maintaining regular dialogue and meetings. ${ }^{19}$

${ }^{18}$ Cabinet approves Pact between EXIM Bank, New Development Bank. New Development Bank, 2016. Available at: http://ndb.int/Cabinet-approves-pact-between-EXIM-Bank-NewDevelopmentBank.php (accessed 08 December 2016).

${ }^{19} \mathrm{NDB}$, Members of BRICS Interbank cooperation mechanism signed MoU on general cooperation. New Development Bank, 2016. Available at: http://ndb.int/NDB-MEMBERS-OFBRICS-INTERBANK-COOPERATION-MECHANISM\%20.php\#parentHorizontalTab2 (accessed 08 December 2016). 
These areas of cooperation were initially identified as priorities in the NDB Policy on Partnerships with National Development Banks approved in December 2015 [New Development Bank, 2015].

It should be noted that, like most other documents on cooperation signed between the NDB and various financial institutions, this Memorandum expresses only declarative intentions and defines potential areas of cooperation, without providing for specific initiatives. Nevertheless, concrete results of cooperation in implementing these documents gradually become apparent. For example, the China Construction Bank participated in the underwriting group for the NDB bond issuance. ${ }^{20} \mathrm{NDB}$ cooperation with other institutions in co-financing of projects is also expected to start in the near future. Following the signing of the Memorandum between the NDB and members of the BRICS Interbank Cooperation Mechanism, Vnesheconombank Chairman Sergei Gorkov noted that "Vnesheconombank would like to expand cooperation with the NDB. In particular, Vnesheconombank is currently forming a portfolio of development projects potentially interesting for the NDB worth up to USD400 million." ${ }^{21}$

In addition, the NDB interacts with other institutions even when declarative documents are not signed. In particular, the construction of the Beloporozhskaya hydroelectric power plants in Karelia provides for the participation of the Eurasian Development Bank (EDB) and the International Investment Bank (IIB). As with other partner institutions at the sub-regional and national levels, the main reason for the NDB's interest in such cooperation was the experience of these banks, their knowledge of national circumstances, and more importantly, the opportunity to use their resources for allocating funds in the national currency, which is one of the most important NDB principles. $^{22}$

The AIIB signed all memoranda and agreements on cooperation with major MDBs with substantial experience and financial resources. As shown below, this approach contributes to the high proportion of projects co-financed by other institutions in the AIIB portfolio. The NDB, while not neglecting partnership with key "traditional” MDBs, also attaches great importance to its interaction with smaller banks, which are familiar with the specifics of the BRICS national markets and make it possible not

${ }^{20}$ BRICS bank to issue $\$ 448 \mathrm{mn}$ of yuan green bonds. The BRICS Post, 2016. Available at: http://thebricspost.com/brics-bank-to-issue-448-mn-of-yuan-green-bonds/\#.WAds-uuhqko (accessed 08 December 2016).

${ }^{21}$ BRICS Interbank Cooperation Mechanism member banks and the New Development Bank announce intention to develop cooperation in priority sectors. Внешэкономбанк, 2015. Available at: http://www.veb.ru/en/press/news/?id_19 $=102691 \&$ filter_year_19 $=2016 \&$ filter_month_19=10 (accessed 08 December 2016).

${ }^{22}$ New Development Bank BRICS Approved the Financing Scheme for Construction of Beloporozhskaya HPPs in the Republic of Karelia. The Official Web Portal of the Republic of Karelia, 2016. Available at: http://www.gov.karelia.ru/News/2016/06/0622_06_e.html (accessed 08 December 2016). 
only to co-finance projects, but also to cooperate in issuing NDB bonds, developing implementation schemes for projects, and other issues.

\section{Prospects of cooperation between the NDB and the AllB}

Despite the similarities between the problems and challenges they face, the new banks, at least at the current stage of their development, are unlikely to actively compete with each other. On the contrary, their similar focus and overlapping country priorities facilitate their potential cooperation, in particular providing syndicated loans for major infrastructure projects. The aspiration for such cooperation was repeatedly confirmed at the high policy level. For example, in their Ufa declaration, the BRICS leaders welcomed "the proposal for the NDB to cooperate closely with existing and new financing mechanisms including the Asian Infrastructure Investment Bank" [BRICS Leaders, 2015]. However, in spite of all these factors and a mutual desire for active cooperation with other multilateral and national financial institutions, direct practical cooperation between the NDB and AIIB has not started yet.

On 1 September 2016, NDB Vice President Zhu Xian announced that the bank was holding talks with the AIIB regarding joint funding of projects. He noted that the banks had established "good relations" and "had already started negotiations on possible forms of cooperation." Firstly, according to Zhu Xian, co-financing of projects was planned, and secondly, the banks had "already signed a relevant agreement on cooperation." However, there is no information about any bilateral agreement between the NDB and AIIB. It is possible that the Joint Declaration of Aspirations on Actions to Support Infrastructure Investment signed by several MDBs was meant (the declaration is discussed further in this article). The NDB Vice President also noted that "At the moment many investment projects are in need of financing," and in this regard the NDB and AIIB "should not compete, but complement each other." The NDB holds the same position with respect to the World Bank, which provides an opportunity to transfer its best practices. ${ }^{23}$ The Memorandum of Understanding between the NDB and the World Bank, analyzed above, supports this view. However, the NDB has not signed such a document with the AIIB yet, and despite the obvious expediency of cooperation between the new development banks, its potential is not fully used.

${ }^{23}$ BRICS NDB, AIIB to start joint financing of projects - NDB VP. New Development Bank, 2016. Available at: http://www.ndb.int/BRICs-NDB-AIIB-to-start-jointfinancing-ofprojectsNDBVP.php (accessed 08 December 2016). 


\section{Co-financing of infrastructure projects by the new and "traditional" MDBs}

Cooperation initiatives between the new development banks and other financial institutions, as noted above, are beginning to yield their first practical results. The NDB's interaction with commercial banks of the BRICS countries contributed to the successful issuance of its bonds on the Chinese market, and shaped plans for future issuance of debt instruments denominated in the BRICS' national currencies in other markets. The AIIB reached agreements on co-financing infrastructure projects with several "traditional" development banks. The main characteristics of these projects are listed below.

The first joint initiative co-financed by the AIIB is the National Slum Upgrading Project in Indonesia. Its aim is to improve access to urban infrastructure and services while supporting the government program carried out in 154 cities in the central and eastern parts of Indonesia [World Bank, 2016]. The project will be co-financed by the World Bank, and the World Banks's procurement policy and environmental and social safeguard policies and procedures will be used for its implementation. This decision was made because of the World Bank standards' full consistency with the provisions of the AIIB Articles of Agreement, and the appropriateness of its monitoring procedures for the project. The total cost of the project will be USD1.743 billion, with USD1.31 billion to be allocated by the Government of Indonesia, and the World Bank and the AIIB providing USD216.5 million each [AIIB, 2016g].

In partnership with the EBRD, the AIIB will implement the Dushanbe-Uzbekistan Border Road Improvement Project. As with the project co-financed by the World Bank, the AIIB decided to use the procedures and standards of the EBRD as a main co-financer and give it the right to administer the project on behalf of the AIIB. Using these advanced standards will allow, in particular, to minimize the negative effects associated with the need to temporarily displace some production and trade units [AIIB, 2016i]. The project's implementation period is from December 2016 to December 2020. Its total cost is USD105.9 million dollars, with USD15.9 million (15\%) provided by the Government of Tajikistan, USD62.5 million (59\%) by the EBRD, and USD27.5 million (26\%) by the AIIB. The AIIB stake in financing is equal to the EBRD's second tranche (USD35 million out of USD62.5 million were allocated by the EBRD earlier, in 2012). The AIIB loan will have a 15-year term (including a grace period of three years) at the standard interest rate for sovereign-backed loans, with an average maturity of 9.25 years, a commitment charge of $0.25 \%$ per year, and a front-end fee of $0.25 \%$. The loan will be based on a semiannual equal amortization scheme (repaid in equal installments every six months) [AIIB, 2016h]. 
Together with the ADB, the AIIB is expected to finance the construction of a 64 $\mathrm{km}$ section of the M4 motorway linking Shorkot to Khanewal in Pakistan's Punjab province. The ADB will act as a lead co-financer and will administer the project on behalf of the AIIB and the UK Department for International Development (DFID). In keeping with tradition, procurement standards, as well as environmental and social safeguards of the partner institution will be used in the project's implementation, given that this partner institution is a "traditional" development bank. In particular, ADB standards will be used to evaluate displacement plans affecting more than 1,300 persons [AIIB, 2016e]. The total cost of the project is USD273 million. USD39 million (14.3\%) will be provided by the Government of Pakistan, 34 million (12.5\%) by the UK Department for International Development, and the AIIB and ADB will provide USD100 million (36.6\%) each. The AIIB loan will have a 20 -year term (including a grace period of five years) at the standard interest rate for sovereign-backed loans, with an average maturity of 12.75 years, and with standard charges and fees. The loan will be based on a semiannual equal amortization scheme [AIIB, 2016d].

Later on the AIIB announced its support for a hydropower plant extension project in Pakistan, financed jointly with the World Bank. Its total cost will be USD823.5 million, with the World Bank contributing USD390 million, USD300 million provided by the AIIB, and USD133.5 million by the national government [AIIB, 2016f].

Thus, the AIIB approved four infrastructure development projects co-financed by other multilateral banks, worth a total of USD2.945 billion. The AIIB will provide loans totaling USD644 million via these projects. There are currently only two projects approved by the AIIB without any participation of co-financing parties, and the total volume of loans via these projects is not more than USD200 million.

Eight AIIB projects are to be implemented in the near future, five of which involve co-financing from the World Bank. ${ }^{24}$ These include: the reconstruction of the $660 \mathrm{~km}$ Karaganda-Burylbaytal motorway at an estimated cost of USD1.47 billion (co-financed by the IBRD with an AIIB loan of USD650 million) [AIIB, 2016a]; a project of energy infrastructure development in the Indian state of Andhra Pradesh (financing details are not yet available) [AIIB, 2016j]; a dam rehabilitation and safety improvement project in Indonesia (financing details are not available yet) [AIIB, 2016b]; and a support project for the Regional Infrastructure Development Fund in Indonesia, whose main task will be to ensure regional authorities' access to funding for local projects in basic infrastructure (the detailed project financing mechanism is not available) [AIIB, 2016c]. The largest project involving the AIIB will be the construction of a pipeline in Azerbaijan. The AIIB contribution will amount to USD600 million, the World Bank will contribute USD800 million, and the EBRD and the EIB will contribute USD1 billion each. The total cost

${ }^{24}$ Proposed Projects. Asian Infrastructure Investment Bank, 2016. Available at: https://www. aiib.org/en/projects/proposed/index.html (accessed 08 December 2016). 
of the project, taking into account financing from private lenders and the borrower, is expected to reach USD8.6 billion. ${ }^{25}$ Despite the lack of complete information on funding schemes for the proposed joint projects, their scale allows us to assume that in the near future the portfolio of projects co-financed by the AIIB and "traditional" development banks will grow at least twofold. The AIIB is also likely to continue co-financing on an equal footing with "traditional" banks, while actively relying on their practices during the preparatory stage and monitoring the implementation of projects.

The NDB's results in terms of co-financing are modest. In addition, no complete information on project financing mechanisms is available. For example, the Russian project of building hydroelectric power plants in Karelia, according to some sources, will be co-financed by the China Gezhouba Group and the Russian Direct Investment Fund, ${ }^{26}$ whereas other sources mention the Eurasian Development Bank as a co-investor. ${ }^{27}$

The main parameters of the NDB and AIIB's interaction with other financial institutions are summarized in Table 1.

Table 1: NDB and AIIB interaction with other financial institutions

\begin{tabular}{|l|l|l|}
\hline World Bank & \multicolumn{1}{|c|}{ NDB } & \multicolumn{1}{c|}{ AIIB } \\
\hline $\begin{array}{l}\text { A Memorandum of Understanding is } \\
\text { signed. Information on joint projects } \\
\text { unavailable }\end{array}$ & $\begin{array}{l}\text { A Co-Financing Framework Agreement is } \\
\text { signed. Joint projects aimed at improving } \\
\text { living conditions in the slums of Indonesia } \\
\text { and the construction of a hydropower } \\
\text { plant in Pakistan are approved. A joint gas } \\
\text { pipeline project in Azerbaijan is discussed }\end{array}$ \\
\hline ADB & $\begin{array}{l}\text { A Memorandum of Understanding is } \\
\text { signed. Information on joint projects } \\
\text { unavailable }\end{array}$ & $\begin{array}{l}\text { A Memorandum of Understanding is } \\
\text { signed. A road reconstruction project } \\
\text { in Pakistan is approved }\end{array}$ \\
\hline EBRD & - & $\begin{array}{l}\text { A Memorandum of Understanding is } \\
\text { signed. A road reconstruction project in } \\
\text { Tajikistan is approved. A joint gas pipeline } \\
\text { project in Azerbaijan is discussed }\end{array}$ \\
\hline $\begin{array}{l}\text { European } \\
\text { Investment Bank }\end{array}$ & $\begin{array}{l}\text { A Memorandum of Understanding is } \\
\text { signed. A joint gas pipeline project } \\
\text { in Azerbaijan is discussed }\end{array}$ \\
\hline $\begin{array}{l}\text { Development } \\
\text { Bank of Latin } \\
\text { America (CAF) }\end{array}$ & $\begin{array}{l}\text { A Memorandum of Understanding is } \\
\text { signed. Information on joint projects } \\
\text { unavailable }\end{array}$ & \multicolumn{1}{|l}{ - } \\
\hline
\end{tabular}

${ }^{25}$ Project Summary Information (PSI). Project No: 000011. Asian Infrastructure Investment Bank, 2016. Available at: https://www.aiib.org/en/projects/approved/2016/_download/trans-anatolian/summary/approved_project_summary_anatolian_natural_gas_pipeline.pdf (accessed 08 December 2016).

${ }^{26}$ BRICS bank receives HPPM project in Karelia worth 10 billion. Vesti, 15 July 2016 (in Russian). Available at: http://www.vestifinance.ru/articles/72976 (accessed 08 December 2016).

${ }^{27}$ BRICS Bank to Finance Indian, Chinese Infrastructure Projects. New Development Bank, 2016. Available at: http://ndb.int/BRICS-Bank-to-finance-Indian-Chinese-infrastructureprojects.php (accessed 08 December 2016). 


\begin{tabular}{|l|l|l|}
\hline & \multicolumn{1}{|c|}{ NDB } & \multicolumn{1}{|c|}{ AIIB } \\
\hline $\begin{array}{l}\text { Eurasian } \\
\text { Development } \\
\text { Bank }\end{array}$ & $\begin{array}{l}\text { No declarative documents on cooperation. } \\
\text { Participates in the provision of funds } \\
\text { denominated in Russian rubles for NDB } \\
\text { projects in Karelia }\end{array}$ & $\begin{array}{l}\text { Cooperation in the development of } \\
\text { transport corridors from China is } \\
\text { discussed }\end{array}$ \\
\hline $\begin{array}{l}\text { International } \\
\text { Investment Bank }\end{array}$ & $\begin{array}{l}\text { No declarative documents on cooperation. } \\
\text { Participates in the provision of funds } \\
\text { denominated in Russian rubles for NDB } \\
\text { projects in Karelia }\end{array}$ & \\
\hline $\begin{array}{l}\text { ICICI (Industrial } \\
\text { Credit and } \\
\text { Investment } \\
\text { Corporation of } \\
\text { India) }\end{array}$ & $\begin{array}{l}\text { A Memorandum of Understanding is } \\
\text { signed. Potential for cooperation in issuing } \\
\text { rupee-denominated bonds }\end{array}$ & \\
\hline $\begin{array}{l}\text { China } \\
\text { Construction } \\
\text { Bank }\end{array}$ & $\begin{array}{l}\text { A Memorandum of Understanding is } \\
\text { signed. Participated in the underwriting } \\
\text { group of the NDB bond issuance }\end{array}$ & \\
\hline $\begin{array}{l}\text { Standard Bank } \\
\text { of South Africa } \\
\text { Limited }\end{array}$ & $\begin{array}{l}\text { A Memorandum of Understanding is } \\
\text { signed. Potential for cooperation in issuing } \\
\text { rupee-denominated bonds }\end{array}$ & \\
\hline $\begin{array}{l}\text { National } \\
\text { development } \\
\text { banks of BRICS } \\
\text { countries (BRICS } \\
\text { Interbank } \\
\text { Cooperation } \\
\text { Mechanism) }\end{array}$ & $\begin{array}{l}\text { A Memorandum of Understanding on } \\
\text { general cooperation is signed. Joint projects } \\
\text { with selected national development banks, } \\
\text { including Vnesheconombank, are discussed }\end{array}$ & \\
\hline
\end{tabular}

Source: compiled by the author.

\section{Joint multilateral initiatives}

Eliminating the deficit in infrastructure investment has become one of the key issues on the G20 agenda in recent years. The G20 considers the optimization of MDBs' operations and the development of cooperation between them in various fields to be one way to address this problem. In 2016, during the Chinese G20 presidency, the NDB and AIIB for the first time participated in this work, along with the main "traditional" MDBs. The main result was the endorsement of a Joint Declaration of Aspirations on actions to support infrastructure investment [World Bank Group, 2016]. The Declaration, adopted with the active contribution of the G20 Infrastructure Investment Working Group, includes "quantitative ambitions for high-quality projects," and their achievement will facilitate additional investment in infrastructure. "The additional infrastructure investment needed... is estimated to be USD1 trillion to USD1.5 trillion annually over the next 15 years" [Multilateral Development Banks, 2016]. In particular, the Declaration refers to documents on cooperation and projects agreed within their framework, between the new and "traditional" MDBs, and also indicates that co-financing will account for a significant share of the new banks' operations, which are expected to reach up to USD1.2 billion in the fiscal year 2016, USD2.5 billion in 
2017, and USD3.5 billion in 2018 for the AIIB, and from USD1.5 to 2 billion, USD2 to 2.5 billion and USD4 to 5 billion for the NDB in the same periods. The Declaration also notes that the "rapid incorporation of the new MDBs in a coordinated and collaborative fashion will allow them to contribute to their maximum potential for the benefit of global infrastructure investment." It is important to mention that the Declaration stems from a Russian initiative launched in 2013 on the creation of a new mechanism intended to provide "genuine additionality and... serve as an innovative model for resource mobilization and infrastructure financing in an environment of increasingly constrained official sector sources of financing" [G20, 2013]. The Russian G20 presidency also initiated the development of the document on "Enhancing the catalytic role of MDBs in mobilizing financing" by the World Bank [G20, 2013].

Despite significant progress, additional efforts are required to maintain the dynamics of cooperation. In this regard, the new MDBs should not only participate in co-financing of projects, but also contribute to "traditional" banks' work at the preparatory stages of project implementation [Multilateral Development Banks, 2016].

The Global Infrastructure Forum, organized for the first time in April 2016, has become a new mechanism for promoting synergies between the NDB, AIIB and "traditional" multilateral development banks. The Forum was attended by representatives of the NDB, AIIB, ADB, AfDB, IDB, EBRD, EIB, the WBG and the Islamic Development Bank. The establishment of the Global Infrastructure Forum is aimed at strengthening cooperation between MDBs in four main areas: project preparation; financing and co-financing of projects; harmonizing operational principles and standards, and sharing best practices; and improving the collection and sharing of data on infrastructure investments. ${ }^{28}$ It was agreed that the Forum would be held annually and organized by one of participating MDBs on a rotational basis. Next year, a special session of the Forum will be devoted to summarizing joint progress in the four abovementioned areas. ${ }^{29}$

Eliminating the gap in infrastructure financing has recently become one of the main G20 priorities. Special attention is being paid to stimulating interaction between multilateral institutions and facilitating joint initiatives in this area. As a result, interaction mechanisms have been launched which involve major MDBs, including the AIIB and NDB. However, it is too early to talk about any concrete activities of these mechanisms or the effectiveness of MDBs' cooperation within them.

${ }^{28}$ Chairman's Statement--Global Infrastructure Forum 2016. World Bank Group, 2016. Available at: http://www.worldbank.org/en/topic/publicprivatepartnerships/brief/chairmans-statement-global-infrastructure-forum-2016 (accessed 08 December 2016).

${ }^{29}$ Unprecedented Collaboration among Development Partners to Improve Infrastructure Implementation. World Bank Group, 2016. Available at: http://www.worldbank.org/en/news/ press-release/2016/04/16/unprecedented-collaboration-among-development-partners-to-improve-infrastructure-implementation (accessed 08 December 2016). 


\section{Conclusion}

The NDB and AIIB recognize the importance of cooperation with other financial institutions with a similar focus, taking into account, on the one hand, their ability to provide co-financing for major infrastructure projects, and on the other hand, the need to exchange experience in selecting and implementing projects, and ensure financing in accordance with the best social and environmental principles, which the new banks lack due to their early stage of formation.

An understanding of this need has contributed to the signing of documents, and the regulating of parameters and areas of such cooperation, with several financial institutions (four available documents for the AIIB and at least eight for the NDB). The NDB has signed memoranda of cooperation with several commercial banks: India's ICICI,${ }^{30}$ the China Construction Bank, ${ }^{31}$ and Standard Bank of South Africa Limited (SBSA) $;{ }^{32}$ as well as with multilateral banks, including the ADB, ${ }^{33}$ the World Bank, ${ }^{34}$ and the Development Bank of Latin America. ${ }^{35}$ It also interacts with the BRICS national development banks via the BRICS Interbank Cooperation Mechanism, and attracts financial partners with country-specific operational experience, without the prior formalization of cooperation, as in the case of the Eurasian Development Bank and the International Investment Bank. The AIIB has signed a Co-Financing Framework Agreement with the World Bank, ${ }^{36}$ and memoranda with the European Investment

${ }^{30}$ New Development, ICICI INK 'Preferred Partner' Pact. New Development Bank, 2016. Available at: http://ndb.int/New-Development-ICICI-ink-preferred-partner-pact.php (accessed 08 December 2016).

${ }^{31}$ New Development Bank Signs MoU With China Construction Bank. BRICS Information Sharing and Exchange Platform, 2016. Available at: http://www.brics-info.org/new-developmentbank-signs-mou-with-china-construction-bank/ (accessed 08 December 2016).

${ }^{2}$ NDB and Standard Bank of South Africa signed a Memorandum on Strategic Cooperation. New Development Bank, 2016. Available at: http://ndb.int/NDB-AND-STANDARD-BANKOF-SOUTH-AFRICA.php\#parentHorizontalTab2 (accessed 08 December 2016).

${ }^{33} \mathrm{NDB}, \mathrm{ADB}$ sign MoU on cooperation for sustainable, inclusive growth. New Development Bank, 2016. Available at:http://www.ndb.int/ndb-adb-sign-mou-on-cooperation-for-sustainableiclusive-growth.php\#parentHorizontalTab2 (accessed 08 December 2016).

${ }^{34}$ World Bank Group, New Development Bank Lay Groundwork for Cooperation. World Bank Group, 2016. Available at: http://www.worldbank.org/en/news/press-release/2016/09/09/worldbank-group-new-development-bank-lay-groundwork-for-cooperation (accessed 08 December 2016).

${ }^{35} \mathrm{CAF}$ and New Development Bank Sign Cooperation Agreement. Development Bank of Latin America, 2016. Available at: https://www.caf.com/en/currently/news/2016/09/caf-and-newdevelopment-bank-sign-cooperation-agreement/ (accessed 08 December 2016).

${ }^{36}$ World Bank and AIIB Sign First Co-Financing Framework Agreement. World Bank Group, 2016. Available at: http://www.worldbank.org/en/news/press-release/2016/04/13/world-bankand-aiib-sign-first-co-financing-framework-agreement (accessed 08 December 2016). 
Bank, ${ }^{37} \mathrm{ADB}^{38}$ and EBRD. ${ }^{39}$ However, the new banks' strategies of cooperation with other institutions differ. The main differences are as follows. The AIIB seeks to establish cooperation primarily with large institutions, with the aim of drawing on their solid experience and using opportunities to participate in large-scale projects based on co-financing. Currently, the majority of AIIB projects are linked to the Chinese "One Belt, One Road" initiative. "Traditional" MDBs, including the ADB and the World Bank, have traditionally been active in countries where these projects are implemented, which explains the AIIB's desire to actively cooperate with them. Thus, in the near future AIIB policy, including cooperation with other institutions, will likely continue to be determined largely by the interests of China as the largest shareholder. The geographical coverage of the bank's projects will undoubtedly expand along with the range of partner institutions, but these processes will take place in line with current trends and dynamics. For instance, potential cooperation between the AIIB and the Eurasian Development Bank is expected to be aimed at the construction of a motorway providing a transport corridor between China and Europe. ${ }^{40}$

The NDB, given its smaller membership and narrow geographical representation, focuses, inter alia, on cooperation with less important institutions, including MDBs with a small number of members, national development banks, and commercial banks. Cooperation with these institutions provides the NDB with the possibility of taking into account not only the best international practices, but also experience of work in specific countries, while providing financing in local currencies, in accordance with the statutory documents of the bank. In addition, NDB cooperation agreements with other banks provide for co-financing, sharing practices and staff exchanges, advisory support for issuing bonds, and improving financial management. The first examples of such cooperation have demonstrated its effectiveness and feasibility. Finally, operational volumes of sub-regional MDBs with a small number of member countries are now often comparable with that of the main "traditional" MDBs (the World Bank, AfDB, ADB, IDB, EBRD). In the future this model of cooperation will likely transform towards strengthening cooperation with major "traditional" MDBs, taking into account the expected expansion of the NDB's membership by 10 to 15 countries.

${ }^{37}$ Asian Infrastructure Investment Bank and European Investment Bank agree to strengthen cooperation. Asian Infrastructure Investment Bank, 2016. Available at: https://www.aiib.org/en/ news-events/news/2016/20160530_001.html (accessed 08 December 2016).

${ }^{38}$ AIIB, ADB sign MOU to strengthen cooperation for sustainable growth. Available at: https:// www.aiib.org/en/news-events/news/2016/20160502_001.html (accessed 08 December 2016).

${ }^{39}$ Asian Infrastructure Investment Bank to cooperate with European Bank for Reconstruction and Development. Asian Infrastructure Investment Bank, 2016. Available at: https://www.aiib.org/ en/news-events/news/2016/20160511_001.html (accessed 08 December 2016).

${ }^{40}$ AIIB and Eurasian Development Bank Discuss Building China-Europe Corridor. Sputnik, 23 March 2016. Available at: https://sputniknews.com/world/201603231036828287-aiib-eurasiandevelopment-bank (accessed 08 December 2016). 
Both strategies used by the NDB and AIIB for building cooperation with other financial institutions are shaped by the new institutions' individual nature, particularly the number of member countries, geographical representation, the interests and influence of individual members, and their priorities, such as improving their image among investors, adapting best practices, planning specific projects, and positioning themselves as development banks of a "new type." Both strategies have their advantages. The AIIB strategy made it possible, in a short period of time, to ensure the participation of other institutions in co-financing projects with a total cost of USD2.945 billion, while the AIIB's contribution amounted to USD644 million. The NDB managed to formalize its cooperation with important local institutions in BRICS countries and to set the stage not only for future joint projects, but also for enhancing the effectiveness of its work in other areas, including raising funds from external sources based on the knowledge and experience of large commercial banks from BRICS countries concerning local capital markets, and providing financing in local currencies. 


\section{References}

AIIB (2016a) Center South Road Corridor Project, Kazakhstan. Available at: http://euweb. aiib.org/uploadfile/2016/0906/20160906120747277.pdf (accessed 16 November 2016).

AIIB (2016b) Indonesia: Dam Operation, Rehabilitation, and Safety Improvement Project (Co-financed with the World Bank). Available at: http://euweb.aiib.org/uploadfile/2016/ 1012/20161012043829912.pdf (accessed 16 November 2016).

AIIB (2016c) Indonesia: Regional Infrastructure Development Fund Project (Co-financed with the World Bank). Available at: http://euweb.aiib.org/uploadfile/2016/1012/20161012 043850498.pdf (accessed 16 November 2016).

AIIB (2016d) Islamic Republic of Pakistan National Motorway M-4 (Shorkot-Khanewal Section) Project. Available at: http://euweb.aiib.org/uploadfile/2016/0706/20160706014 503464.pdf (accessed 16 November 2016).

AIIB (2016e) Pakistan: National Motorway M-4 (Shorkot-Khanewal Section) Project (Cofinanced with the Asian Development Bank). Available at: http://euweb.aiib.org/uplo adfile/2016/0706/20160706014440100.pdf (accessed 16 November 2016).

AIIB (2016f) Pakistan: Tarbela 5 Hydropower Extension Project (T5HEP) (Co-financed with the World Bank). Available at: http://euweb.aiib.org/uploadfile/2016/1012/20161012 024536253.pdf (accessed 16 November 2016).

AIIB (2016g) Project Summary Information (PSI). Available at: http://euweb.aiib.org/upl oadfile/2016/0718/20160718091153373.pdf (accessed 16 November 2016).

AIIB (2016h) Republic of Tajikistan Dushanbe-Uzbekistan Border Road Improvement Project. Available at: http://euweb.aiib.org/uploadfile/2016/0706/20160706014350620. pdf (accessed 16 November 2016).

AIIB (2016i) Tajikistan: Dushanbe-Uzbekistan Border Road Improvement Project (Cofinanced with the European Bank for Reconstruction and Development). Available at: http://euweb.aiib.org/uploadfile/2016/0706/20160706014326702.pdf (accessed 16 November 2016).

AIIB (2016j) India: Andhra Pradesh 24x7 - Power for All Project (Cofinanced with the World Bank). Available at: http://euweb.aiib.org/uploadfile/2016/1012/201610120438087 20.pdf (accessed 16 November 2016).

AIIB and ADB (2016) Memorandum of Understanding for Strengthening Co-operation between Asian Development Bank and Asian Infrastructure Investment Bank. Available at: http://euweb.aiib.org/uploadfile/2016/0606/20160606043053695.pdf (accessed 16 November 2016).

AIIB and EIB (2016) Memorandum of Understanding between the Asian Infrastructure Investment Bank and the European Investment Bank. Available at: http://euweb.aiib.org/ uploadfile/2016/0606/20160606043225638.pdf (accessed 16 November 2016). 
Barone B. and Spratt S. (2015) Development Banks from the BRICS. IDS. Available at: https://opendocs.ids.ac.uk/opendocs/bitstream/handle/123456789/5781/ER111_DevelopmentBanksfromtheBRICS.pdf;jsessionid=36C5788A605FAC208C15BD330ECD0169? sequence $=1$ (accessed 16 November 2016).

Bhattacharya A., Oppenheim J., Stern N. (2015) Driving Sustainable Development Through Better Infrastructure: Key elements of a Transformation Program. Available at: https://www. brookings.edu/wp-content/uploads/2016/07/07-sustainable-development-infrastructure-v2.pdf (accessed 16 November 2016).

BRICS Leaders (2015) VII BRICS Summit Ufa Declaration, Ufa, 9 July. Available at: http://brics2016.gov.in/upload/files/document/5763c20a72f2d7thDeclarationeng.pdf (accessed 16 November 2016).

EBRD and AIIB (2016) Memorandum of Understanding between the European Bank for Reconstruction and Development and the Asian Infrastructure Investment Bank. Available at: http://euweb.aiib.org/uploadfile/2016/0606/20160606043148338.pdf (accessed 16 November 2016).

G20 (2013) Workplan on Financing for Investment. Available at: (accessed 16 November 2016).

G20 Leaders (2014) G20 Leaders' Communiqué. Available at: http://www.g20.utoronto. ca/2014/2014-1116-communique.html (accessed 16 November 2016).

Griffith-Jones S. (2014) A BRICS Development Bank: A Dream Coming True? UNCTAD Discussion Paper, no 215. Available at: http://unctad.org/en/PublicationsLibrary/osgdp20141_en.pdf (accessed 16 November 2016).

Humphrey C. (2015) Developmental Revolution or Bretton Woods Revisited? The Prospects of the BRICS New Development Bank and the Asian Infrastructure Investment Bank. ODI Working Paper 418. Available at: https://www.odi.org/sites/odi.org.uk/files/ odi-assets/publications-opinion-files/9615.pdf (accessed 16 November 2016).

Multilateral Development Banks (2016) MDBs Joint Declaration of Aspirations on Actions to Support Infrastructure Investment. Available at: http://g20.org/English/Documents/Current/201608/P020160815360318908738.pdf (accessed 16 November 2016).

New Development Bank (2015) Policy on Partnerships with National Development Banks. Available at: http://ndb.int/pdf/ndb-policy-on-partnerships-with-national-developmentbanks-20160121.pdf (accessed 16 November 2016).

World Bank (2016) Project Information Document. Available at: http://www-wds.worldbank.org/external/default/WDSContentServer/WDSP/EAP/2016/03/01/090224b0841c3 9e7/1_0/Rendered/PDF/Project0Inform0ng0Program000P154782.pdf (accessed 16 November 2016).

World Bank Group (2016) Closing the Infrastructure Gap. Available at: http://www. un.org/esa/ffd/wp-content/uploads/2016/01/Closing-the-infrastructure-gap_WorldBank-Group_IATF-Issue-Brief.pdf (accessed 16 November 2016). 